Gut, 1978, 19, 655-663

\title{
Gastrointestinal somatostatin: extraction and radioimmunoassay in different species
}

\author{
C. MCINTOSHי1, R. ARNOLD, E. BOTHE, H. BECKER, J. KÖBBERLING, AND \\ W. CREUTZFELDT
}

From the Department of Medicine, Division of Gastroenterology and Metabolism, University of Göttingen, Federal Republic of Germany

SUMMARY A radioimmunoassay capable of detecting $300 \mathrm{fg}$ somatostatin has been developed and levels of the polypeptide in gastrointestinal tissues from man, dog, and rat have been measured. Rapid freezing of collected samples and careful control of extraction is necessary. Concentrations in different regions of dog antrum ( $425 \pm 50$ to $773 \pm 254 \mathrm{ng} / \mathrm{g}$ tissue) are similar to those in antrum from duodenal ulcer patients and control subjects: $614 \pm 125$ and $465 \pm 104 \mathrm{ng} / \mathrm{g}$ tissue respectively. Levels in histologically normal human pancreas $(253 \pm 43 \mathrm{ng} / \mathrm{g}$ tissue) are comparable with those in dog pancreas $(333 \pm 66 \mathrm{ng} / \mathrm{g}$ tissue), whereas in two cases of neonatal hypoglycaemia the concentration exceeded $3000 \mathrm{ng} / \mathrm{g}$ tissue. On gel chromatography the majority of immunoreactive somatostatin elutes as the synthetic tetradecapeptide and a small fraction as a larger species.

Somatostatin exerts potent inhibitory action on the release of a number of gastrointestinal and pancreatic hormones. The in vivo secretion of insulin (Alberti et al., 1973; Koerker et al., 1974; Ward et al., 1975), glucagon (Dobbs et al., 1975), gastrin (Bloom et al., 1974; Arnold et al., 1975), secretin (Boden et al., 1975), gastric inhibitory polypeptide (Pederson et al., 1975) and motilin (Bloom et al., 1975) are suppressed under normal or pathological conditions by somatostatin infusion. Inhibition of insulin (Efendic et al., 1974; Okamoto et al., 1975), glucagon (Iversen, 1974), and gastrin (Hayes et al., 1975) release has been demonstrated with in vitro systems. In addition, somatostatin infusion causes direct inhibition of gastric secretion (Bloom et al., 1974; Arnold et al., 1975; Arnold and Creutzfeldt, 1975), pancreatic juice and enzyme secretion and gall bladder contraction (Creutzfeldt et al., 1975; Lankisch et al., 1975).

Apart from the brain, somatostatin has been shown by immunohistochemistry to occur in the pancreas, stomach, duodenum, and jejunum (Luft et al., 1974; Goldsmith et al., 1975; Dubois, 1975; Polak et al., 1975; Rufener et al., 1975), and specific localisation to the D-cell has been reported (Polak et al., 1975; Rufener et al., 1975). Direct measurement of somatostatin in rat and chicken tissues by

${ }^{1}$ Present address: Dept. of Physiology, University of British Columbia, Vancouver, BC, Canada.

Received for publication 5 January 1978 radioimmunoassay (Arimura et al., 1975a,b; Weir et al., 1976; Kronheim et al., 1976; Vale et al., 1976) has confirmed the gastrointestinal localisation. Release of immunoreactive somatostatin from isolated pancreatic islets incubated in vitro, and from the perfused pancreas, occurs in the presence of a number of physiological stimuli (Schauder et al., 1976, 1977a,b; Barden et al., 1976; Patton et al., 1976a,b), suggesting a role for somatostatin as a regulator of pancreatic secretion. The present communication examines the importance of collection and extraction procedures for measurement of somatostatin in the gastrointestinal tract and the levels of the polypeptide in these tissues from man, dog, and rat.

\section{Methods}

\section{IMMUNISATION}

One milligram of synthetic cyclic somatostatin (lot no. 4999, Serono, Freiburg (Br) Germany) was dissolved in $200 \mu \mathrm{l}$ distilled water. To the peptide was added $8 \mathrm{mg}$ bovine serum albumin (Behringwerke, Marburg/Lahn, Germany) in $1 \mathrm{ml}$ water and, dropwise, $50 \mathrm{mg}$ 1-ethyl 3(3-dimethylamino-propyl)carbodiimide $\mathrm{HCl}$ (Sigma) dissolved in $500 \mu \mathrm{l}$ distilled water. The reaction mixture was shaken gently, left at room temperature for four hours and the suspension dialysed for $\mathbf{4 8}$ hours against distilled water at $4^{\circ} \mathrm{C}$. When ${ }^{125} \mathrm{I}$-somatostatin was added to the coupling mixture $71.6 \pm 3.4 \%$ (eight coup- 
lings) of the radioactivity was retained during dialysis. The mass of lyophilised conjugate was $9 \cdot 5 \pm 0 \cdot 1 \mathrm{mg}$ (eight couplings). Molar coupling ratios were therefore between 3.6 and $5.0 \mathrm{~mol}$ somatostatin per $\mathrm{mol}$ albumin.

The conjugate was emulsified in an equal volume of Freund's complete adjuvant and injected intradermally in the neck of New Zealand white rabbits in a dose of $250 \mu \mathrm{g}$ per animal. Immunisation was repeated three times at monthly intervals and 10 days after each immunisation blood was taken from an ear vein for testing antibody reactivity by radioimmunoassay.

IODINATION OF SOMATOSTATIN AND PURIFICATION OF THE LABELLED PEPTIDE Iodination of 1-Tyr-somatostatin was performed by a slight modification of the method of Greenwood et al. (1963). In a reaction volume of $30 \mu \mathrm{l}, 1 \mathrm{mCi}$ 125I was reacted with $5 \mu \mathrm{g}$ 1-Tyr-somatostatin (Serono, Freiburg, Germany) by the addition of $20 \mu \mathrm{g}$ chloramine-T. After a 15 second incubation the reaction was terminated by the addition of $50 \mu \mathrm{g}$ sodium metabisulphite. The labelled peptide was separated from free ${ }^{125}$ I and 'damaged' material by adding hormone free plasma $(1 \mathrm{ml})$ followed by $20 \mathrm{mg}$ QUSO G32 (Philadelphia Quartz Co., USA). After centrifugation the pellet was washed twice with $1 \mathrm{ml}$ distilled water, the labelled somatostatin eluted with acetic acid/acetone/water $(0 \cdot 1: 3 \cdot 9: 4 \cdot 0)$, diluted with $0 \cdot 1 \mathrm{M}$ acetic acid containing $0.05 \%$ human serum albumin, and lyophilised. A mean of $59 \pm 3 \%$ (nine iodinations) of initial radioactivity was eluted from the QUSO G32. Before use in the assay the ${ }^{125}$ I-somatostatin was purified on a CM-cellulose column (Whatman CM 52) essentially by the method of Arimura et al. (1975a). The lyophilised material $\left(1-3 \times 10^{6} \mathrm{cpm}\right)$ was dissolved in $1 \mathrm{ml} 0.002 \mathrm{M}$ ammonium acetate (pH 4.6) and applied to the CM-cellulose equilibrated in the same buffer. After washing the column with $20 \mathrm{ml} 0.002 \mathrm{M}$ ammonium acetate the assay tracer was eluted with $0.2 \mathrm{M}$ ammonium acetate (pH 4.6) (Fig. 1).

Approximately $90 \%$ of added counts appeared in the major peak with freshly labelled material. Fractions from the top of the peak and those from the descending limb, amounting to $40-45 \%$ of the peak radioactivity, gave equally good assays and had specific activities of $900-1100 \mu \mathrm{Ci} / \mu \mathrm{g}$. The overall elution was reproducible over a three month period, although the first peak demonstrated a significant increase.

The purification of ${ }^{125}$ I-somatostatin by such ionexchange chromatography resulted in a marked improvement in the assay: with freshly labelled

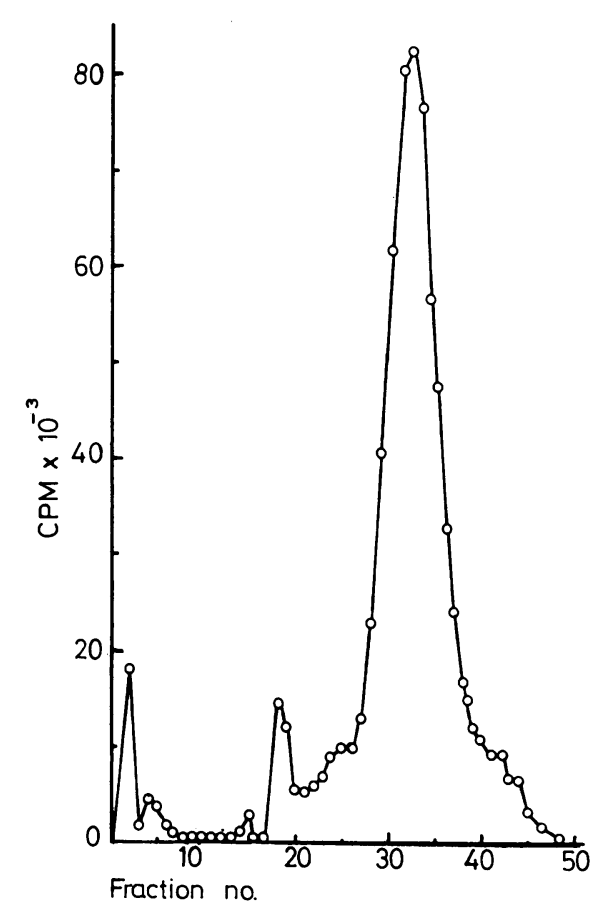

Fig. 1 Purification of ${ }^{125}$ I-somatostatin on CMcellulose. ${ }^{125} I$-somatostatin was applied to a $C M$ cellulose (CM 52) column $(5 \times 1 \mathrm{~cm})$ in $0.002 \mathrm{M}$ ammonium acetate pH 4.6 and the column washed with $24 \mathrm{ml}$ of the same buffer. Purified tracer was eluted with $0.2 \mathrm{M}$ ammonium acetate $\mathrm{pH} 4.6$ and fractions 31-33 pooled for the assay.

material the unspecific binding decreased from $10 \%$ to $2.5 \%$ and a five-fold increase in assay sensitivity was achieved.

\section{CONDITION OF ASSAY}

Incubations were carried out in triplicate in glass tubes for 48 hours at $4^{\circ} \mathrm{C}$. The total incubation volume of $400 \mu \mathrm{l}$ consisted of $100 \mu \mathrm{l}$ antiserum, $100 \mu \mathrm{l}$ synthetic cyclic somatostatin standard or unknown, $100 \mu \mathrm{l}{ }^{125}$ I-Tyr somatostatin $(0.5 \mathrm{f} \mathrm{mol})$, and $100 \mu 1$ diluent buffer. Diluent buffer consisted of $50 \mathrm{mM}$ barbital buffer (pH 7.4) containing merthiolate $(0.01 \%), 500 \mathrm{KIU} / \mathrm{ml}$ aprotinin (Trasylol, Bayer), and $1 \%$ human serum albumin. Separation of bound and free antigen was achieved by the dextran coated charcoal method; $2.5 \mathrm{~g}$ charcoal (Norit A) and 0.5 g Dextran T70 (Pharmacia, Sweden) were mixed in $200 \mathrm{ml} 0.05 \mathrm{M}$ phosphate buffer ( $\mathrm{pH} \mathrm{7.4)}$ and stirred for at least 30 minutes at $4^{\circ} \mathrm{C}$. One millilitre of the mixture was added to each tube and after vortex mixing the tubes were centrifuged at $3000 \mathrm{rpm}$ for 15 minutes at $4^{\circ} \mathrm{C}$. After the supernatant was decanted both bound and 
free fractions were counted in an automatic $\gamma$ spectrometer.

TISSUE COLLECTION AND EXTRACTION

Tissues from dogs were removed under anaesthesia and kept under a variety of conditions (as described in the text) before storage at $-20^{\circ} \mathrm{C}$. Rat tissues were removed after cervical dislocation and snap frozen on dry ice. All animals had starved for at least 12 hours before removal of tissue and, to ensure that the rats had completely empty stomachs, the period of starvation was preceded by three days on a liquid formula diet (Vivasorb, Pfrimmer, Erlangen, Germany).

Tissue sampling during endoscopy was performed after an overnight fast and after intravenous injection of $10 \mathrm{mg}$ diazepam immediately before the start of gastroscopy. Surgical biopsies were obtained during operations for duodenal ulcer. Antrum mucosa was excised $1-3 \mathrm{~cm}$ proximal to the pylorus. Corpus mucosa was obtained from the greater curvature opposite to the angle of the stomach. Resected pancreas was collected as soon as possible after the operative procedure. Inevitable delays between operation and subsequent freezing, and the relative heterogeneity of material, may partly contribute to the wide interpatient variation as discussed in the text.

Control stomach samples were from subjects with normal basal and pentagastrin stimulated gastric secretion and consisted of normal volunteers, patients with dyspeptic complaints, or patients undergoing duodenopancreatectomy as a result of chronic pancreatitis. Histologically normal pancreatic specimens were from clinically normal accident cases (two) or patients with VernerMorrison syndrome (one), Zollinger-Ellison syndrome (one), or insulinoma (11).

Unless otherwise stated, for extraction the frozen tissue was quickly weighed, boiled for 15 minutes in $0.2 \mathrm{M}$ acetic acid $(10 \mathrm{mg} / \mathrm{ml})$ and homogenised with an Ultratorax homogeniser. Solid material was removed by centrifugation (10000 $g 10$ minutes) and the clear supernatant lyophilised. For assay, the extract was dissolved in distilled water and suitably diluted with diluent buffer. All extracts were measured in a minimum of three dilutions and when results differed by more than $10 \%$ the sample was reassayed.

\section{GEL-FILTRATION CHROMATOGRAPHY}

Chromatography was performed on columns of Sephadex G25 fine $(100 \times 1 \mathrm{~cm})$. Elution was with $0.2 \mathrm{M}$ acetic acid at a flow rate of $5 \mathrm{ml} / \mathrm{h}$. Collected fractions $(1 \mathrm{ml})$ were lyophilised and dissolved in assay buffer. Void volume (Vo) and total volume
(Vt) were determined using blue dextran and 125I respectively. SOM indicates the elution position of synthetic cyclic somatostatin.

\section{EXPRESSION OF RESULTS}

All data presented are in the form mean \pm SEM with the number of experiments or measurements in brackets (n).

\section{Results}

\section{ASSAY}

Cyclic somatostatin conjugated to bovine serum albumin was relatively immunogenic and produced antibodies in all four rabbits immunised after two immunisations, which bound $50 \%$ of tracer at titres ranging from 1:200 to 1:8000. Assays with these antibodies were capable of detecting $2 \mathrm{pg}$ cyclic somatostatin per assay tube. In current assays using an antibody after three immunisations (No. $\mathrm{VI} / 3 / 1$ ) at a dilution of 1:12500 concentrations as low as 300 femtogram can be detected with $95 \%$ confidence (Fig. 2). No cross-reaction occurred with a number of other hormones tested including LHRH, TSH, insulin, proinsulin, secretin, and glucagon

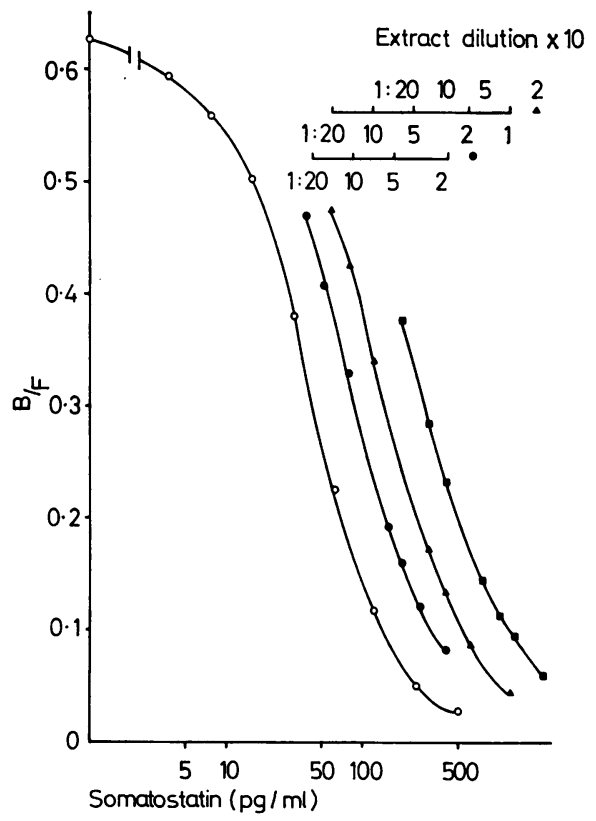

Fig. 2 Displacement of ${ }^{125}$ I-somatostatin by cyclic somatostatin and dilutions of tissue extracts. Cyclic somatostatin $(O)$ or various dilutions of extracts from human pancreas $(\Delta)$, stomach antrum $(\square)$ or corpus $(O)$ were incubated with antibody VI/III/1 at a dilution of $1: 12500$. 
(which share a common tetrapeptide with somatostatin), CCK, motilin, and gastrin at concentrations up to $1 \mu \mathrm{g}$. In a series of 10 assays intra-assay variations were $7 \%$ and $4 \%$, and inter-assay variations $16 \%$ and $12 \%$, for concentrations of $15 \mathrm{pg} / \mathrm{ml}$ and $125 \mathrm{pg} / \mathrm{ml}$ respectively. Dilutions of extracts from human stomach antrum or corpus, and pancreas (Fig. 2) and canine or rat extracts from stomach antrum and corpus, duodenum, and pancreas (not shown) were completely superimposable on the standard curves of all tested antibodies. Other cyclic somatostatin preparations and analogues show varying immunoreactive potency (Table 1).

TISSUE COLLECTION AND EXTRACTION The mode of tissue collection was found to be important for all tissues except duodenum (Table 2). Significantly lower levels were routinely obtained when samples were allowed to remain at room temperature for relatively short periods of time. All subsequent studies were therefore performed with material which was immediately placed on dry ice. Careful control of the extraction procedure was necessary. Boiling the tissue in $0.2 \mathrm{M}$ acetic acid for 15 minutes followed by homogenisation consistently gave the best results. Shorter periods of boiling or

Table 1 Relative immunoreactive potencies of different somatostatin preparations

\begin{tabular}{ll}
\hline & $\begin{array}{l}\text { Relative immunoreactive } \\
\text { potency (\%) }\end{array}$ \\
\hline Cyclic somatostatin (Serono) & 100 \\
Cyclic somatostatin (Kabi) & 100 \\
Cyclic somatostatin (Bioscience) & 50 \\
Tyr-1 somatostatin (Serono) & 53 \\
Tyr-11 somatostatin (Serono) & 35 \\
Linear somatostatin (Serono) & 15 \\
Des Ala'-Gly's-somatostatin (Serono) & 14 \\
\hline
\end{tabular}

Displacement curves with the polypeptides were plotted by Logit-Log transformation and the midrange dose (Logit $\mathrm{B} / \mathrm{B}_{0}=0$ ) obtained. Cyclic somatostatin (Serono) was taken as $100 \%(=28 \mathrm{f} \mathrm{mol} /$ tube $)$ and relative potencies calculated for the other polypeptides. reversal of this procedure gave lower levels of somatostatin (Table 3). A number of further experiments were performed in order to validate the extraction procedure.

Extracts from rat liver or kidney contained undetectable amounts of somatostatin. Addition of synthetic somatostatin to liver and kidney (500 $\mathrm{pg} / \mathrm{mg}$ ) followed by extraction gave respective recoveries of $101 \pm 3 \%$ and $75 \pm 8 \%(n=4)$. Rat corpus samples from fed rats extracted with either $0.2 \mathrm{M}$ or $2 \mathrm{M}$ acetic acid yielded levels of $109.3 \pm$ 10.6 and $112.5 \pm 13.4 \mathrm{ng} / \mathrm{g}$ tissue $(\mathrm{n}=6)$ respectively. Hydrochloric acid/ethanol mixtures have been used for extraction of pancreatic islets, as this is the normal medium used for insulin extraction, and resulted in recoveries of $86 \cdot 6 \pm 1 \cdot 1 \%(n=10)$.

Experiments in which rat antrum was extracted and the sediment from the centrifugation twice re-extracted gave levels of $81 \cdot 5 \pm 15 \cdot 2,12 \cdot 0 \pm 3 \cdot 0$, and $1.9 \pm 0.4 \mathrm{ng} / \mathrm{g}$ tissue $(\mathrm{n}=4)$ for the three extractions. Assuming that the total extracted somatostatin approached $100 \%$, then approximately $90 \%$ is removed by a single extraction. A human pancreas extracted by methods (c) and (d) of Table 3 and measured with three different antibodies gave values of 434,428 , and $420 \mathrm{ng} / \mathrm{g}$ tissue and 350,280 , and $330 \mathrm{ng} / \mathrm{g}$ tissue respectively.

Somatostatin concentrations in gastrointestinal tissues of starved rats are given in Table 4. Highest levels were found in stomach antrum and corpus, with lower levels in pancreas and duodenum. In the dog highest levels of somatostatin were found in the antrum and decreasing levels in the order: pancreas (head) $>$ pancreas (processus uncinatus) $=$ pancreas $($ tail) $=$ stomach (corpus) $>$ proximal duodenum (Table 2). The regional distribution in dog stomach measured in multiple biopsy specimens is shown in Fig. 3. Levels in the corpus were uniform throughout the greater curvature but were significantly lower in regions 3 and 7 of the lesser curvature. In the antrum, concentrations of somatostatin showed considerable variation between individual

Table 2 Effect of collection procedure on somatostatin concentration in extracts of dog gastrointestinal tissues

\begin{tabular}{|c|c|c|c|c|c|c|}
\hline \multirow[t]{3}{*}{ Collection procedure } & \multicolumn{6}{|c|}{ Somatostatin $n g / g$ tissue $($ mean $\pm S E M)$} \\
\hline & \multicolumn{2}{|l|}{ Stomach } & \multicolumn{3}{|l|}{ Pancreas } & \multirow[t]{2}{*}{ Duodenum } \\
\hline & Antrum & Corpus & Head & $\begin{array}{l}\text { Processus } \\
\text { uncinatus }\end{array}$ & Tail & \\
\hline $\begin{array}{l}\text { A Dry ice } \\
\text { B Ice } \\
\text { C Room temp. } 45 \mathrm{~min} \\
\text { Number of animals }\end{array}$ & $\begin{array}{l}467 \pm 139 \\
493 \pm 114 \\
337 \pm 71 \\
6\end{array}$ & $\begin{array}{l}189 \pm 52 \\
195 \pm 33 \\
148 \pm 35 \\
6\end{array}$ & $\begin{array}{l}301 \pm 68 \\
333 \pm 66 \\
259 \pm 59 \\
6\end{array}$ & $\begin{array}{l}195 \pm 48 \\
205 \pm 41 \\
138 \pm 13 \\
4\end{array}$ & $\begin{array}{l}178 \pm 14 \\
187 \pm 27 \\
177 \pm 35 \\
4\end{array}$ & $\begin{array}{l}97 \pm 30 \\
98 \pm 17 \\
91 \pm 21 \\
6\end{array}$ \\
\hline
\end{tabular}

Tissue specimens were removed from dogs, immediately placed in vessels containing the substances shown (collection procedure), and subs $2-$ quently stored at $-20^{\circ} \mathrm{C}$ before extraction and assay as described in Methods section. 
Table 3 Extraction of somatostatin from human pancreas by different procedures

\begin{tabular}{|c|c|c|c|}
\hline \multirow[t]{3}{*}{ Extraction procedure } & \multicolumn{3}{|c|}{ Somatostatin concentration ( $\mathrm{ng} / \mathrm{mg}$ protein) } \\
\hline & \multicolumn{2}{|l|}{$A$} & \multirow[t]{2}{*}{$B$} \\
\hline & 1 & 2 & \\
\hline $\begin{array}{l}\text { a. Boiled } 2 \mathrm{~min} \text {. Homogenised } 2 \mathrm{~min} \\
\text { b. Homogenised } 2 \mathrm{~min} \text {. Boiled } 2 \mathrm{~min} \\
\text { c. Boiled } 15 \mathrm{~min} \text {. Homogenised } 2 \mathrm{~min} \\
\text { d. Homogenised } 2 \mathrm{~min} \text {. Boiled } 15 \mathrm{~min}\end{array}$ & $\begin{array}{c}1 \cdot 35 \\
2 \cdot 60 \\
24 \cdot 48 \\
15 \cdot 00\end{array}$ & $\begin{array}{c}2 \cdot 21 \\
2 \cdot 11 \\
19 \cdot 23 \\
15 \cdot 30\end{array}$ & $\begin{array}{r}1.96 \\
4 \cdot 42 \\
39 \cdot 00 \\
19 \cdot 35\end{array}$ \\
\hline
\end{tabular}

Specimens of human pancreas $(90-150 \mathrm{mg}$ ) from two different subjects (A and B) were added to $0 \cdot 2 \mathrm{M}$ acetic acid $(10 \mathrm{mg} / \mathrm{ml}$ ) and subjected to the above extraction procedures. The mixture was then centrifuged, the supernatant lyophilised and assayed for somatostatin. Further details in Methods section. With pancreas A duplicate samples were extracted.

Table 4 Somatostatin concentration in gastrointestinal tissues from starved rats

\begin{tabular}{ll}
\hline Tissue & Somatostatin concentration (ng/g tissue) \\
\hline Stomach-antrum & $50 \cdot 2 \pm 4 \cdot 9(14)$ \\
Stomach-corpus & $46 \cdot 3 \pm 3 \cdot 1(15)$ \\
Pancreas & $33 \cdot 4 \pm 3 \cdot 4(14)$ \\
Duodenum & $17 \cdot 3 \pm 1 \cdot 3(18)$ \\
\hline
\end{tabular}

Rats (200-300 g) were killed by cervical dislocation, the tissues removed and snap frozen on dry ice. Extraction was performed as described in Methods section. Values given are the mean \pm SEM; numbers in parentheses indicate the number of rats.

dogs but the overall levels in all but region 11 were fairly constant. The level in sample 8 is intermediate between those of antrum and corpus, and was shown histologically to contain a mixture of both cell types.

Concentrations of somatostatin in human gastrointestinal tissues demonstrated a broad intersubject variation (Table 5). Human antrum from both control and duodenal ulcer patients contained similar mean levels to those found in the dog. At the present time the number of control corpus samples is too small to allow any definitive statement to be made as to whether there is any significant difference from duodenal ulcer patients. The mean level of somatostatin in histologically normal pancreas, despite the wide range, was similar to that in dog. Only a small group of patients with pancreatitis have been investigated and of these five had levels under $80 \mathrm{ng} / \mathrm{g}$ tissue and the remaining two had levels of 305 and $1425 \mathrm{ng} / \mathrm{g}$ tissue. In the extracts of pancreata from two children with neonatal hypoglycaemia due to nesidioblastosis, and the tissue from the one child having in addition a focal islet adenomatosis, extremely high concentrations of somatostatin were measured (Table 5).

\section{GEL FILTRATION CHROMATOGRAPHY OF} EXTRACTS

Gel filtration chromatography profiles from extracts of human antrum, corpus, and pancreas are shown

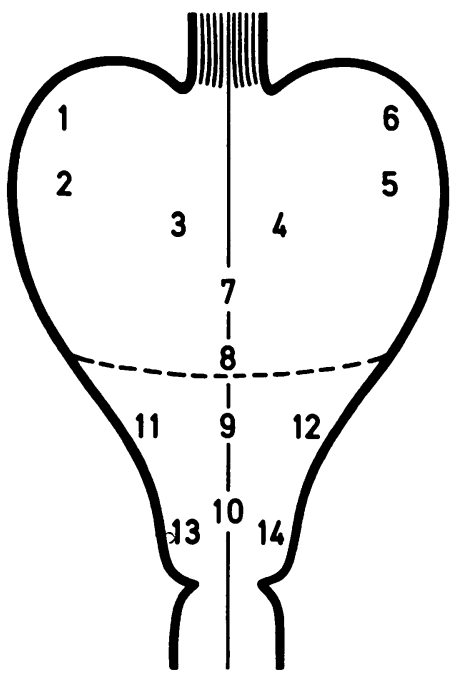

Fig. 3 Somatostatin distribution in dog stomach.

Biopsy specimens were removed from different regions of the dog stomach, snap frozen on dry ice and stored at $-20^{\circ} \mathrm{C}$. Extraction and assay as described in Methods section. Number of dogs $=4$.

$\begin{array}{llll}\text { Region } & \begin{array}{l}\text { Somatostatin } \\ \text { concentration } \\ \text { (ng/g tissue } \\ \text { mean } \pm \text { SEM) }\end{array} & \text { Region } & \begin{array}{l}\text { Somatostatin } \\ \text { concentration } \\ (\text { ng/g tissue }\end{array} \\ \text { mean } \pm \text { SEM) } \\ 1 & 124 \pm 10 & 8 & 386 \pm 215 \\ 2 & 131 \pm 18 & 9 & 517 \pm 130 \\ 3 & 60 \pm 18 & 10 & 425 \pm 50 \\ 4 & 113 \pm 49 & 11 & 773 \pm 254 \\ 5 & 98 \pm 19 & 12 & 463 \pm 213 \\ 6 & 141 \pm 35 & 13 & 537 \pm 181 \\ 7 & 65 \pm 20 & 14 & 581 \pm 181\end{array}$

in Fig. 4. A small peak, eluting in the region of the void volume, and a major peak eluting at the same position as tetradecapeptide somatostatin were present in all three chromatographic separations. This distribution is also seen with dog or rat gastrointestinal extracts. With two from 24 studied extracts heterogeneity has been observed in the region of tetradecapeptide somatostatin. Corpus 
Table 5 Somatostatin concentration in human stomach and pancreas

\begin{tabular}{llll}
\hline Organ & Clinical state of patient & \multicolumn{2}{c}{ Somatostatin concentration ng/g tissue } \\
\cline { 3 - 4 } & & Mean \pm SEM & Range \\
\hline Stomach: antrum & Control (15) & $465 \pm 104$ & $22-1500$ \\
Stomach: corpus & Duodenal ulcer (24) & $614 \pm 125$ & $23-2250$ \\
Pancreas & Control (6) & $294 \pm 144$ & $65-992$ \\
& Duodenal ulcer (16) & $478 \pm 170$ & $19-2500$ \\
& Control (15) & $253 \pm 43$ & $31-640$ \\
& Chronic pancreatitis (7) & $270 \pm 196$ & $2-1425$ \\
& Neonatal hypoglycaemia (nesidioblastosis) (2) & (a) 3200; (b) 4840 & Case a: adenomatosis 5500 \\
\hline
\end{tabular}

Biopsy specimens from stomach antrum or corpus and resected pancreas were collected and processed as described in Methods section. See also under this section for the clinical state of subjects classified as 'control'. The number in parentheses indicates the number of sample extracts .

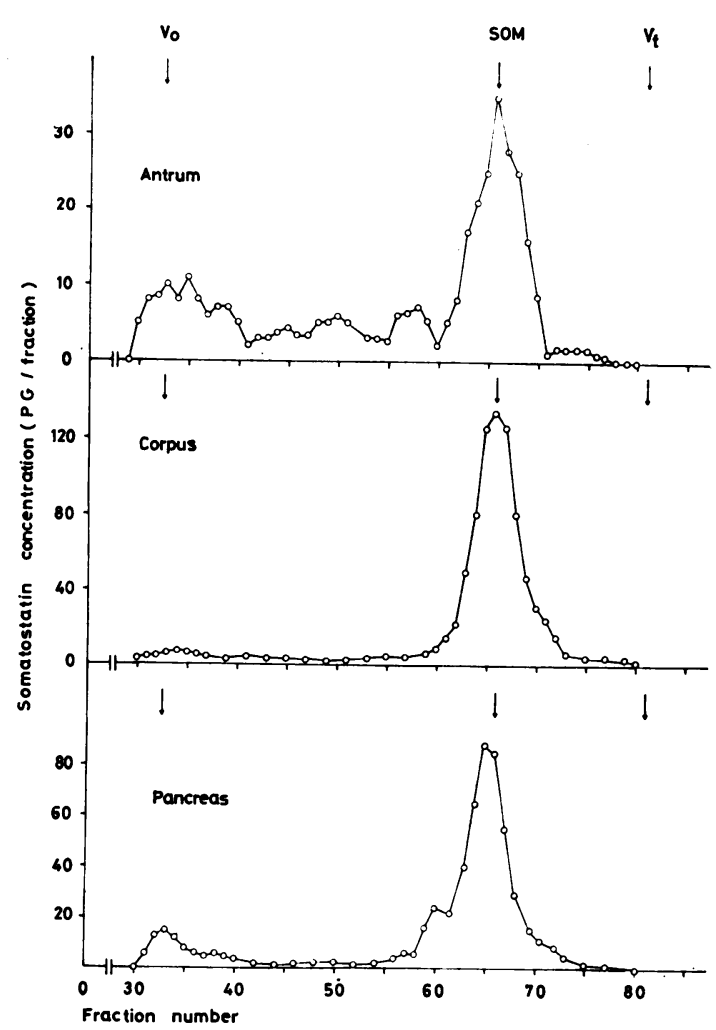

Fig. 4 Gel-chromatography of extracts from human stomach antrum and corpus, and human pancreas. Stomach biopsy specimens from a patient with a duodenal ulcer and resected pancreas from a patient with chronic pancreatitis were extracted and processed as described in Methods section. Chromatography was performed on columns of Sephadex G25 fine $(100 \times 1 \mathrm{~cm})$. Elution was with $0.2 \mathrm{M}$ acetic acid at a flow rate of $5 \mathrm{ml} / \mathrm{h}$. Collected fractions $(1 \mathrm{ml})$ were lyophilised and dissolved in assay buffer. Void volume (Vo) and total volume (Vt) were determined using blue dextran and ${ }^{125}$ I respectively. SOM indicates the elution position of synthetic cyclic somatostatin. from a patient with gastric ulcer and pancreas from a patient with chronic pancreatitis (Fig. 5) contained a further species eluting just before cyclic somatostatin. These peaks were reproducible on a second chromatography.

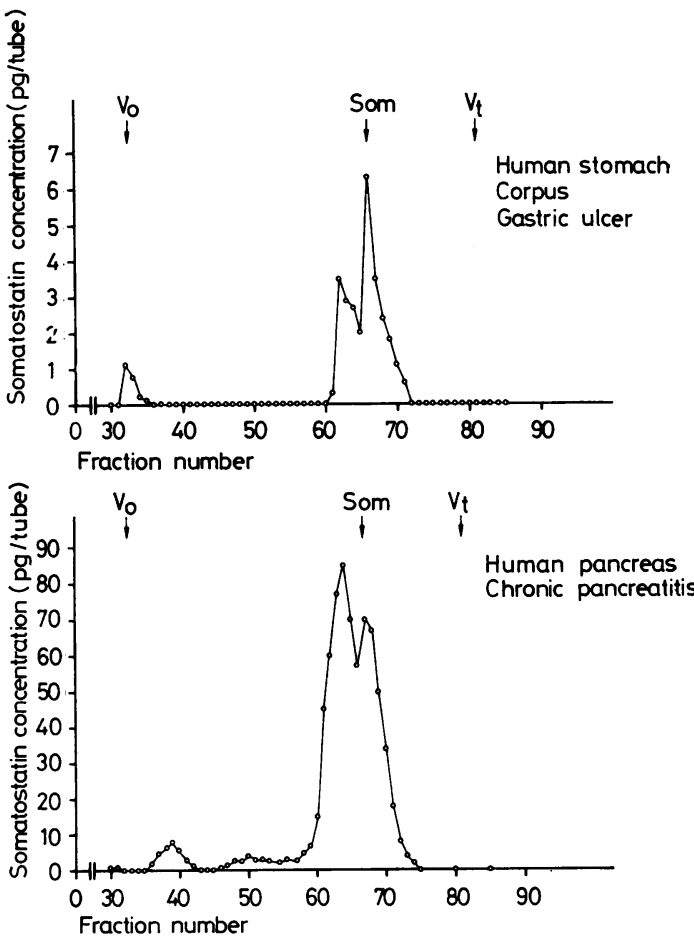

Fig. 5 Gel-chromatography of human gastrointestinal extracts demonstrating heterogeneity in the region of tetradecapeptide somatostatin. Human stomach corpus extract from a patient with a gastric ulcer and pancreas extract from a patient with chronic pancreatitis were submitted to gel-chromatography as described for Fig. 4. Note the double peak in the region of tetradecapeptide somatostatin. 


\section{Discussion}

The presence of material in gastrointestinal tissues which is immunologically identical to somatostatin substantiates proposals that the observed suppression of hormone secretion and direct inhibition of different gastrointestinal target organs by this polypeptide are of physiological interest. The close proximity of somatostatin cells to G-cells in the antrum, and to A- and B-cells in the pancreatic islet, indicate a possible paracrine (Feyrter, 1953; Creutzfeldt, 1976) rather than an endocrine function. Evidence that pancreaticoduodenal vein plasma levels of somatostatin increase in response to glucose infusion, whereas peripheral levels remain constant, is in agreement with this suggestion (Schusdziarra et al., 1977). However, further investigation of changes in tissue content and in circulating levels of somatostatin are needed and a highly sensitive radioimmunoassay is required. The increase in assay sensitivity compared to published methods (Arimura et al., 1975a,b; Weir et al., 1976; Kronheim et al., 1976; Vale et al., 1976) may be due to the characteristics of the antibody and the high specific activity of the labelled polypeptide. Vale et al. (1976) have analysed the binding characteristics of several antibodies raised against different antigens. Glutaraldehyde coupled cyclic somatostatin produced antibody sensitive to changes in amino acids $\mathrm{Asn}^{5}$, $\mathrm{Phe}^{7}$ Lys $^{9}$ and Phe ${ }^{11}$, while antibody against bisdiazotized benzidine coupled $\mathrm{Tyr}^{11}$-somatostatin detected changes in the $\mathrm{N}$-terminal region $\mathrm{Ala}^{1}-\mathrm{Phe}^{6}$. Antigen produced by a carbodiimide coupling method similar to that described here gave antibody which reacted less strongly with analogues having changes in the region $\mathrm{Asn}^{5}$-Trp ${ }^{8}$ and $\mathrm{Phe}^{11}$. Although only a limited number of analogues have been tested with the present antibody, both changes at $\mathrm{Phe}^{11}$ and at the $\mathrm{N}$-terminus reduced the immunological potency, but the fact that linear somatostatin reacts to only $15 \%$ of the cyclic form suggests that conformational changes may also be important.

The method of collection and subsequent extraction of tissue is critical for validation of differences between tissues and in tissue content in response to stimuli. Rapid cooling of specimens on collection is evidently advisable, as even 45 minutes at room temperature is sufficient to give significantly reduced levels. In addition, a sufficient period of boiling before extraction is also important. This procedure is probably necessary in order to inactivate proteolytic enzymes but the cells may also be rendered more susceptible to disruption by homogenisation after boiling. The experiments designed to further validate that the majority of endogenous somatostatin was extracted by the present technique indicate that yields approached $90 \%$ after the single extraction and that $\mathbf{0 . 2} \mathrm{M}$ or $2 \mathrm{M}$ acetic acid, or acetic acid ethanol mixtures, give quantitatively similar yields. The somatostatin concentration in extracts from dog and rat showed the highest levels in stomach antrum and lowest levels in the duodenum. In the dog, stomach corpus, the processus uncinatus and tail of the pancreas contain equivalent amounts of somatostatin and the head of the pancreas is intermediate between antrum and these regions. Comparison of the levels found in rat tissues with published data reveals some discrepancies. Concentrations of $340 \mathrm{ng} / \mathrm{g}$ tissue (Vale et al., 1976) and $142 \mathrm{ng} / \mathrm{g}$ tissue (Arimura et al., 1975b) have been reported for rat pancreatic extracts, whereas in the present study the amount was $33 \mathrm{ng} / \mathrm{g}$ tissue. Similarly, extracts of stomach antrum and corpus, and duodenum gave lower values than those of Arimura et al. (1975b). Kronheim et al. (1976) found approximately 15 -fold more somatostatin ( $\mathrm{ng} / \mathrm{mg}$ protein) in antrum as compared to the body of the stomach. As all published reports (including the present) appear to have used extracts from whole rat tissues rather than biopsy samples these disparities are likely to have other causes including the metabolic status of the animal before slaughter, differences in extraction technique, in antibody characteristics, and in the assay itself.

With the present assay system only a small amount of 'big somatostatin' (Arimura et al., 1975b) is detected. Other workers have found varying amounts of 'big somatostatin' in extracts from normal pancreas (Weir et al., 1976; Dupont and AlvaradoUrbina, 1976) and pancreatic tumour tissue (Larsson et al., 1977). Evidence that it can be partially converted by urea treatment to a form eluting in a position identical to that of tetradecapeptide somatostatin indicates that it is probably either an aggregate of somatostatin or somatostatin noncovalently bound to a larger protein. The low amount detected by our assay suggests that the antigenic determinants are hidden in this form. However, at least part of 'big somatostatin' may be purely artefactual because of the relatively high protein content in the region of the void volume, particularly in unboiled extracts. Further heterogeneity of gastrointestinal somatostatin may, nevertheless, exist as shown for somatostatinoma extracts (Larsson et al., 1977) and for the two examples presented here (Fig. 5). It remains to be resolved as to whether these species are produced only under pathological conditions and what relationship they have to immunoreactive somatostatin eluting in the position of the synthetic cyclic tetradecapeptide.

Direct comparison of the somatostatin concentration in dog and human tissues with those in rat is not possible, as the former were obtained with biopsy 
specimens. The multiple biopsies taken from dog stomach show that there is a certain patchy distribution of D-cells and even neighbouring specimens may differ by $30-40 \%$ in content This may partially explain the large interindividual variation observed with human specimens. Nevertheless, the concentrations found in the different regions of the dog antrum (425 \pm 50 to $773 \pm 254 \mathrm{ng} / \mathrm{g}$ tissue) are of a similar level to those found in both duodenal ulcer patients and control subjects: $614 \pm 125$ and $465 \pm 104 \mathrm{ng} / \mathrm{g}$ tissue respectively. Concentrations in human corpus from duodenal ulcer patients were higher than those in dog but, at present, it is not yet certain whether the difference from control subjects is significant owing to the small number of the latter group. Concentrations of somatostatin in pancreatic samples from patients with either a histologically normal pancreas or chronic pancreatitis also showed a wide distribution. This may be at least partly due to loss of some somatostatin owing to the time between operation and freezing of some of the samples and to the relative heterogeneity of the samples that were obtained (see: Methods-Collection procedures). The mean level ( $253 \pm 43 \mathrm{ng} / \mathrm{g}$ tissue) in the 'normal' group is, however, similar to the concentration in an equivalent region of the dog pancreas $(301 \pm 68 \mathrm{ng} / \mathrm{g}$ tissue).

No definite statement can be made on the effect of chronic pancreatitis on somatostatin concentration because of the limited number of cases but, of the seven specimens studied, five had levels under $80 \mathrm{ng} / \mathrm{g}$ tissue, an amount found in only two of the control pancreata. The extremely high levels in the two children with nesidioblastosis (and surgically-proven islet cell hyperplasia, including B-, A- and D-cells) may be characteristic for the pancreas in neonatal hypoglycaemia but, as fresh pancreatic tissue of normal babies is not available for comparison, this cannot be verified.

It must be emphasised that, despite the immunological similarity between the material extracted from these tissues and hypothalamic somatostatin, confirmation of identity awaits purification and sequencing of the extrahypothalamic polypeptide. Nevertheless, as raised levels have been found in islets from streptozotocin diabetic rats (Patel and Weir, 1976) and release of immunoreactive somatostatin from isolated pancreatic islets and the perfused pancreas has been domonstrated (Schauder et al., 1976, 1977a,b; Barden et al., 1976; Patton et al., 1976a,b), it is evident that somatostatin responds to functional changes in the pancreatic islet. Further investigations must concentrate on changes of the somatostatin tissue content in the gastrointestinal tract under normal and pathological conditions, and substantiate the reported stimulation of local blood levels in response to physiological stimuli.

\section{References}

Alberti, K. G. M. M., Christensen, N. J., Christensen, S. -E., Hansen, A. P., Iversen, J., Lundbaek, K., Seyer-Hansen, K., and Ørskov, H. (1973). Inhibition of insulin secretion by somatostatin. Lancet, 2, 1299-1301.

Arimura, A., Sato, H., Coy, D. H., and Schally, A. V. (1975a). Radioimmunoassay for GH-release inhibiting hormone. Proceedings of the Society for Experimental Biology and Medicine, 148, 784-789.

Arimura, A., Sato, H., Dupont, A., Nishi, N., and Schally, A. V. (1975b). Somatostatin: abundance of immunoreactive hormone in rat stomach and pancreas. Science, 189, 1007-1009.

Arnold, R., and Creutzfeldt, W. (1975). Hemmung der pentagastrininduzierten Säuresekretion des Magens beim Menschen durch Somatostatin. Deutsche medizinische Wochenschrift, 100, 1014-1016.

Arnold, R., Köbberling, J., Track, N. S., and Creutzfeldt, W. (1975). Lowering of basal and stimulated serum immunoreactive gastrin and gastric secretion in patients with Zollinger-Ellison syndrome by somatostatin (Abstract). Acta Endocrinologica, Supplement, 193, 75.

Barden, N., Alvarado-Urbina, G., Coté, J.-P., and Dupont, A. (1976). Cyclic AMP-dependent stimulation of somatostatin secretion by isolated rat islets of Langerhans. Biochemical and Biophysical Research Communications, 71, 840-844.

Bloom, S. R., Mortimer, C. H., Thorner, M. O., Besser, G. M., Hall, R., Gomez-Pan, A., Roy, V. M., Russell, R. C. G., Coy, D. H., Kastin, A. J., and Schally, A. V. (1974). Inhibition of gastrin and gastric-acid secretion by growth-hormone release-inhibiting hormone. Lancet, 2, 1106-1109.

Bloom, S. R., Ralphs, D. N., Besser, G. M., Hall, R., Coy, D. H., Kastin, A. J., and Schally, A. V. (1975). Effect of somatostatin on motilin levels and gastric emptying (Abstract). Gut, 16, 834.

Boden, G., Sivitz, M. C., Owen, O. E., Essa-Koumar, N., and Landor, J. H. (1975). Somatostatin suppresses secretin and pancreatic exocrine secretion. Science, 190, 163-164.

Creutzfeldt, W. (1976). Effects of gastrointestinal hormones -physiological or pharmacological? Conference on Stimulus-Secretion Coupling in the Gastrointestinal Tract, 27-29 May 1975. Edited by R. M. Case and H. Goebell. MTP: Lancaster.

Creutzfeldt, W., Lankisch, P. G., and Fölsch, U. R. (1975). Hemmung der Sekretin-und Cholezystokinin-Pankreozymin-induzierten Saft-und Enzymsekretion des Pancreas und der Gallenblasenkontraktion beim Menschen durch Somatostatin. Deutsche medizinische Wochenschrift, 100, 1135-1138.

Dobbs, R., Sakurai, H., Sasaki, H., Faloona, G., Valverde, I., Baetens, D., Orci, L., and Unger, R. (1975). Glucagon: role in the hyperglycemia of diabetes mellitus. Science, 187, 544-547.

Dubois, M. P. (1975). Immunoreactive somatostatin is present in discrete cells of the endocrine pancreas. Proceedings of the National Academy of Science USA, 72, 1340-1343.

Dupont, A., and Alvarado-Urbina, G. (1976). Conversion of big pancreatic somatostatin without peptide bond cleavage into somatostatin tetradecapeptide. Life Sciences, 19, 1431-1434. 
Efendic, S., Luft, R., and Grill, V. (1974). Effect of somatostatin on glucose induced insulin release in isolated perfused rat pancreas and isolated rat pancreatic islets. FEBS Letters, 42, 169-172.

Feyrter, E. (1953). Über die peripheren endokrinen (parakrinen). Drüsen des Menschen. 2nd ed. Maudrich: Wien.

Goldsmith, P. C., Rose, J. C., Arimura, A., and Ganong, W. F. (1975). Ultrastructural localization of somatostatin in pancreatic islets of the rat. Endocrinology, 97, 1061-1064.

Greenwood, F. C., Hunter, W. M., and Glover, J. S. (1963). The preparation of $\mathbf{1}^{\mathbf{1 3 1}}$-labelled human growth hormone of high specific radioactivity. Biochemical Journal, 89, 114-123.

Hayes, J. R., Johnson, D. G., Koerker, D., and Williams, R. H. (1975). Inhibition of gastrin release by somatostatin in vitro. Endocrinology, 96, 1374-1376.

Iversen, J. (1974). Inhibition of pancreatic glucagon release by somatostatin: in vitro. Scandinavian Journal of Clinical and Laboratory Investigation, 33, 125-129.

Koerker, D. J., Ruch, W., Chideckerl, E., Palmer, J., Goodner, C. J., Ensinck, J., and Gale, C. C. (1974). Somatostatin: hypothalamic inhibitor of the endocrine pancreas. Science, 184, 482-484.

Kronheim, S., Berelowitz, M., and Pimstone, B. L. (1976). A radioimmunoassay for growth hormone release-inhibiting hormone: method and quantitative tissue distribution. Clinical Endocrinology, 5, 619-630.

Lankisch, P. G., Arnold, R., and Creutzfeldt, W. (1975). Wirkung von Somatostatin auf die betazol-stimulierte Magensekretion und die carbachol-stimulierte Pankreassekretion und Gallenblasenkontraktion des Menschen. Deutsche medizinische Wochenschrift, 100, 1797-1800.

Larsson, L. -I., Hirsch, M. A., Holst, J. J., Ingemansson, S., Kühl, C., Lindkaer-Jensen, S., Lundqvist, G., Rehfeld, J. F., and Schwartz, T. W. (1977). Pancreatic somatostatinoma: clinical features and physiological implications. Lancet, 1, 666-668.

Luft, R., Efendic, S., Hökfelt, T., Johansson, O., and Arimura, A. (1974). Immunohistochemical evidence for the localization of somatostatin-like immunoreactivity in a cell population of the pancreatic islets. Medical Biology, 52, 428-430.

Okamoto, H., Noto, Y., Miyamoto, S., Mabuchi, H., and Takeda, R. (1975). Inhibition by somatostatin of insulin release from isolated pancreatic islets. FEBS Letters, 54, 103-105.

Patel, Y. C., and Weir, G. C. (1976). Increased somatostatin content of islets from streptozotocin-diabetic rats. Clinical Endocrinology, 5, 191-194.

Patton, G. S., Dobbs, R., Orci, L., Vale, W., and Unger,
R. H. (1976a). Stimulation of pancreatic immunoreactive somatostatin (IRS) release by glucagon. Metabolism, 25, (Suppl. 1), 1499.

Patton, G. S., Ipp, E., Dobbs, R. E., Orci, L., Vale, W., and Unger, R. H. (1976b). Response of pancreatic immunoreactive somatostatin to arginine. Life Sciences, 19, 1957-1960.

Pederson, R. A., Dryburgh, J. R., and Brown, J. C. (1975). The effect of somatostatin on release and insulinotropic action of gastric inhibitory polypeptide. Canadian Journal of Physiology and Pharmacology, 53, 1200-1205.

Polak, J. M., Pearse, A. G. E., Grimelius, L., Bloom, S. R., and Arimura, A. (1975). Growth-hormone releaseinhibiting hormone in gastrointestinal and pancreatic D-cells. Lancet, 1, 1220-1222.

Rufener, C., Dubois, M. P., Malaisse-Lagae, F., and Orci, L. (1975). Immuno-fluorescent reactivity to anti-somatostatin in the gastro-intestinal mucosa of the dog. Diabetologia, 11, 321-324.

Schauder, P., McIntosh, C., Arends, J., Arnold, R., Frerichs, H., and Creutzfeldt, W. (1976). Somatostatin and insulin release from isolated rat pancreatic islets stimulated by glucose. FEBS Letters, 68, 225-227.

Schauder, P., McIntosh, C., Arends, J., Arnold, R., Frerichs, H., and Creutzfeldt, W. (1977a). Somatostatin and insulin release from isolated rat pancreatic islets in response to D-glucose, L-leucine, $a$-ketoisocaproic acid or D-glyceraldehyde: Evidence for a regulatory role of adenosine $-3^{\prime}, 5^{\prime}$-cyclic monophosphate. Biochemical and Biophysical Research Communications, 75, 630-635.

Schauder, P., McIntosh, C., Panten, U., Arends, J., Arnold, R., Frerichs, H., and Creutzfeldt, W. (1977b). Dynamics of somatostatin release from isolated rat pancreatic islets. FEBS Letters, 81, 355-358.

Schusdziarra, V., Dobbs, R. E., Harris, V., and Unger, R. H. (1977). Immunoreactive somatostatin levels in plasma of normal and alloxan diabetic dogs. FEBS Letters, 81, 69-72.

Vale, W., Ling, N., Rivier, J., Villarreal, J., Rivier, C., Douglas, C., and Brown, M. (1976). Somatostatin: anatomic and phylogenetic distribution of somatostatin. Metabolism, 25, Supplement, 1, 1491-1494.

Ward, F. R., Leblanc, H., and Yen, S. S. C. (1975). The inhibitory effect of somatostatin on growth hormone, insulin and glucagon secretion in diabetes mellitus. Journal of Clinical Endocrinology and Metabolism, 41, 527-532.

Weir, G. C., Goltsos, P. C., Steinberg, E. P., and Patel, Y. C. (1976). High concentration of somatostatin immunoreactivity in chicken pancreas. Diabetologia, 12, 129-132. 